\title{
Research Article: Screening sesame (Sesamum indicum L.) germplasm for thermo-tolerance
}

\section{T. SHOBHA RANI AND T. KIRANBABU}

Article Chronicle: Received : 17.07.2017;

Accepted : 01.08 .2017

KEY WoRDS : Sesame, Thermo tolerance, Flowering, Seed filling, Sesamum indicum $\mathrm{L}$.

Author for correspondence :

\section{T. SHOBHA RANI}

Regional Agricultural Research Station

(P.J.T.S.A.U.), Polasa, JAGTIAL (TELANGANA) INDIA

Email: shobhapjtsau@ gmail.com
SUMMARY : Germplasm comprising of 442 sesame genotypes were evaluated under thermo-stress conditions to identify thermo tolerant genotypes during 2013-14 and 2014-15 at Regional Agriculture Research Station, Polasa, Jagtial district, Telangana state. Same set of material was evaluated in nonstress conditions. The material was exposed to thermo-stress $\left(>40^{\circ} \mathrm{C}\right)$ during flowering, capsule formation and seed development for two weeks in 2013-14 and for four weeks in 2014-15. Data was recorded on 25 randomly selected plants from each entry for number of seeds per capsule, 1000- seed weight and seed yield /plant during both years. Thermo-effect was expressed as ratio of stressed / non-stressed plants. The effects of thermo stress were lesser in shorter period exposure and more drastic in prolonged exposure of the genotypes to high temperatures. Four entries JCS 2846, JCS 2892, JCS 3102 and JCS 3258 showed maximum seed development and survival. This study revealed that these genotypes can be utilized in breeding programme for development of sesame varieties having thermo-tolerance at reproductive growth and developmental stages.

How to cite this article : Rani, T. Shobha and Kiranbabu, T. (2017). Screening sesame (Sesamum indicum L.) germplasm for thermo-tolerance. Agric. Update, 12(TECHSEAR-6) : 1553-1556; DOI: 10.15740/HAS/AU/12. TECHSEAR(6)2017/1553-1556. 